\title{
MAIN FACTORS LIMITING THE RECOGNITION AND USE OF KEY MANAGEMENT ACCOUNTING TOOLS AND ISSUES IN HOSPITALITY INDUSTRY
}

\author{
Halil Akmese 8* $^{*}$ \\ Tevfik Eren ${ }^{9}$ \\ Sercan Aras ${ }^{10}$ \\ Aysegul Ilhan ${ }^{11}$
}

\begin{abstract}
As it is in the world, tourism in Turkey has the potential for rapid development and it provides opportunities for many different sectors to develop. It is necessary for accommodation establishments which have a considerable share in tourism sector to provide productivity and efficiency within the internal process of an establishment in order to reach their expected profit goals and continue their existence because they have a labor-intensive structure, they encounter many different cultures, demands of consumers continually differ and they carry on a business in a dynamic environment. To manage this purpose, managers of accommodation establishments want to use proper and reliable financial information in the decision-making process in order to protect the existence of an establishment, minimize errors or remove them and evaluate activities of an establishment. In this context, an effective management accounting system supports the decision-making process and enables financial information which is required to minimize cost in further periods, increase sales revenues and provide a competitive advantage for an establishment. The purpose of this research is to investigate management accounting and its applications in accommodation establishments, detect problems and determine to what extent applications of management accounting are benefitted.
\end{abstract}

\section{INTRODUCTION}

It might be stated that leading actors in tourism sector is accommodation establishments. (Doğan,Ö.;Kırlığlu,H.;2016). The dynamic structure of tourism sector and rapid developments, competitive market conditions that accommodation establishments experience, technological innovations and customer satisfaction coming to the forefront, unique and different services presented by accommodation establishments among their competitors necessitate an effective management and system understanding in order to provide a competitive advantage and continue their

\footnotetext{
$8^{*}$ Corresponding Author, Necmettin Erbakan University, Faculty of Tourism, Department of Tourism Management, halilakmese@gmail.com, hakmese@konya.edu.tr

${ }^{9}$ Necmettin Erbakan University,

${ }^{10}$, Necmettin Erbakan University, Faculty of Tourism, Department of Tourism Management, arassercan1@gmail.com

${ }^{11}$ Necmettin Erbakan University, Institute of Social Sciences, Department of Tourism Management

+ This research is supported academically and financially by the Scientific Research Projects Department of Necmettin Erbakan University. Project number: 172518001-219
} 
operations. In this context, owners or managers of accommodation establishments foresee obtaining reliable information at any time they want and applying this information in time in terms of making plans for future, applying and controlling them. It is only possible with a cost and management accounting organization in an establishment. Management accounting in accommodation businesses defined as a unit that provides information for administrators who are responsible for the management and control of activities (Jagels \& Ralston; 2006).

Developing technology and computer systems enable establishments to receive data and information which were not possible before. For accommodation establishments, one of those areas in which these developments are applied most effectively is cost and management accounting. Main purpose lying under these efforts is to increase the efficiency and productivity of decision-makers throughout the organization by providing the required information (Drury; 2012)

Because of the service that accommodation establishments provide for 24 hours a day, 365 days a year, they function like a factory which continuously operates. It is a necessity for managers of accommodation establishments serving in this way to give particular importance to consumer satisfaction. In order to achieve this goal accommodation establishments need to strengthen their financial structures and they require methods related to cost control. At this point, the significance of accounting information system is great for accommodation establishments. Accounting information systems are the backbone of all establishments including accommodation establishments. Accounting information systems in an establishment might be defined as processing units including both operations of traditional accounting and management processes such as management accounting, cost accounting and operating budget.

Management accounting is a branch of accounting which provide digital information that managers of an establishment need while making correct decisions. The purpose of management accounting is to provide necessary information that managers of an establishment need in decision-making process and prepare, interpret, obtain financial reports and supply these reports for management departments in time.

Tourism is a sector in which demands continually vary, uncertainty and risk exist at any time, cost and expense control becomes difficult day by day and rates of obtained profit continually change by the effect of strong competitive environment. Accommodation establishments are also largely affected by these changes because accommodation establishments as establishments using fixed capital in a large measure must be in a state of flux in order to use their investment in a profitable way and meet expectations of customers.

In this case, only those establishments which succeed in managing uncertainty in the best way by making correct decisions might survive. Thus, managers' decision making process which is a vital issue might reach a successful end by supplying required data properly and reliably at the desired time. Since the financial and non-financial information which is required by managers in order to continue the existence of their 
establishments and struggle against difficulties in market conditions is obtained by means of management accounting, management accounting becomes particularly significant in accommodation establishments.

\section{LITERATURE REVIEW}

Before beginning an academic research, the first thing to do is to gather similar researches related to the topic. When previous researches related to the topic are examined, it is often observed that they include topics about accounting. In the research managed by Arzu et. al. (2015) on the hotels in Cappadocia region, the relationship between the intensity of using management accounting tools by the hotels and organizational strategies employed by the hotels was investigated. The results of the research display that the hotels use the detailed budgeting system, which is one of traditional management tools, and strategic management accounting is preferred. This is because the hotels do not have enough technical knowledge as they are small-scale establishments.

In the research done by Özdoğan (2010) on Anemon chain hotels using qualitative research techniques, it was determined that management accounting is one of the most effective systems used by establishments in order to respond to changing conditions and developments positively and shape these changes.

Pavlatos and Paggios (2009) conducted a research to determine the management accounting tools used in accommodation establishments in Greece. The results of the research show that the management accounting tools (such as budgeting, customer profitability analysis) are substantially employed and, besides, techniques such as modern management accounting, activity-based budgeting are also regarded.

In his thesis, Angay (2003) managed a research in order to investigate the cost and management accounting applications of 4 and 5 star hotels in Antalya region. The results of the research show that factors of external environment must be continually followed in order to obtain profit goals of hotels, staff and managers who are among internal environment factors must internalize the same goals, a faster and more balanced development is provided by using management accounting information in decision-making process.

Angelakis, Theriu \& Floropoulos (2010) have aimed with their research to determine the rate of use of traditional and new management accounting implementations in Greek businesses and to measure the similarities and differences of the results by comparing with the results of Finland.

Sulaiman Ahmad \& Alwi (2004) searched that the adoption level of traditional management accounting and strategic management accounting applications in Malaysia, Singapore, China and India. At the end of the analysis, in four Asian countries, it is determined that the use of strategic management accounting is insufficient, but the use of traditional management accounting is beneficial. 
Within the scope of this research the scale developed by Damito and Schmidgall (2010) is used as the foundation of research questionnaire.

\section{FINDINGS}

As it is summarized in table 1 findings revealed that all of the participants have idea or a degree of knowledge on the management accounting tools. Nearly 5\% of the participants responded that they have no idea about the directed proposals related to management accounting applications in accommodation industry. It might be claimed that this might be due to the professional origins of the managers. In some cases departmental managers might came from the front line operations and they might develop their professional careers by means of internal recruitment. This type of managers might be handicapped with regard to their technical knowledge which is generally gained by university education. High rates of responses provided by the participants might be evaluated as the validation of study and proposal. As the participants have technical knowledge about management accounting applications they are able to evaluate the usefulness of management accounting tools and they might be aware of the obstacles related to these tools and issues. It is apparent from the findings that income statement analysis, financial statements analysis and operation budgeting are three most famous and frequently referred management accounting tools among the accommodation managers. These tools are evaluated as they are easy to learn and could be applied within the hotel reporting system. At least $85 \%$ of the respondents reported that these management accounting tools are easy to learn and use. Inventory management, break-even analysis, cash budgeting, financial forecasting, internal auditing, variance analysis and balance sheet analysis seem to be placed as not frequently used or known as the income statement analysis, operation budgeting and financial statements analysis. Regarding to the capital budgeting, flexible budgeting and financial knowledge (use of sources and funds) it might be stated that nearly $28 \%$ of the respondents thought that these tools are not widespread among industry professionals and $5 \%$ of them thought that these are time taking processes. Break even analysis seem to be evaluated as the most time taking management accounting tool (nearly $11 \%$ of the responses) but on the other hand this tool is used nearly $80 \%$ of the respondents. Regarding to these responses it might be stated that break even analysis is the most frequently benefited management accounting tool regardless of its time taking nature. With respect to the costs concerns operation budgeting, internal auditing, variance analysis and flexible budgeting are evaluated by a small minority of the respondents (approximately $4 \%$ of the respondents) as these management accounting tools are increasing the costs in relation to the number and qualifications of the personnel who are able to apply these tools. 
Table 1: Summary of responses regarding to management accounting tools.

\begin{tabular}{|c|c|c|c|c|c|c|c|c|c|c|c|c|c|}
\hline & \multirow[t]{2}{*}{$\begin{array}{c}\text { Management } \\
\text { accounting tools }\end{array}$} & \multicolumn{2}{|c|}{$\begin{array}{l}\text { Easy to learn } \\
\text { and apply }\end{array}$} & \multicolumn{2}{|c|}{\begin{tabular}{|c|} 
Not \\
widesprea \\
d among \\
profession \\
als or not \\
easy to \\
learn
\end{tabular}} & \multicolumn{2}{|c|}{$\begin{array}{l}\text { Time } \\
\text { consumin } \\
\text { g to apply }\end{array}$} & \multicolumn{2}{|c|}{$\begin{array}{c}\text { Applicatio } \\
\text { n } \\
\text { increases } \\
\text { the costs }\end{array}$} & \multicolumn{2}{|c|}{$\begin{array}{c}\text { Not } \\
\text { applicable } \\
\text { in } \\
\text { accommo } \\
\text { dation } \\
\text { industry }\end{array}$} & \multicolumn{2}{|c|}{ No idea } \\
\hline & & $\%$ & $\mathrm{n}$ & $\%$ & $\mathrm{n}$ & $\%$ & $\mathrm{n}$ & $\%$ & $\mathrm{n}$ & $\%$ & $\mathrm{n}$ & $\%$ & $\mathrm{n}$ \\
\hline 1. & $\begin{array}{l}\text { Income statement } \\
\text { analysis }\end{array}$ & 86,2 & 100 & 3,4 & 4 & 6,9 & 8 & 0 & 0 & 3,4 & 4 & 0 & 0 \\
\hline 2. & Operation Budgeting & 86,2 & 100 & 3,4 & 4 & 3,4 & 4 & 3,4 & 4 & 0 & 0 & 3,4 & 4 \\
\hline 3. & $\begin{array}{l}\text { Financial statements } \\
\text { analysis }\end{array}$ & 84,7 & 104 & 6,9 & 8 & 0 & 0 & 0 & 0 & 0 & 0 & 3,4 & 4 \\
\hline 4. & Inventory management & 82,8 & 96 & 6,9 & 8 & 3,4 & 4 & 0 & 0 & 0 & 0 & 3,4 & 4 \\
\hline 5. & Break even analysis & 79,3 & 92 & 6,9 & 8 & 10,3 & 12 & 0 & 0 & 0 & 0 & 3,4 & 4 \\
\hline 6. & Cash Budgeting & 79,3 & 92 & 13,8 & 16 & 3,4 & 4 & 0 & 0 & 0 & 0 & 3,4 & 4 \\
\hline 7. & Financial forecasting & 79,3 & 92 & 13,8 & 16 & 6,9 & 8 & 0 & 0 & 0 & 0 & 0 & 0 \\
\hline 8. & Internal auditing & 79,3 & 92 & 6,9 & 8 & 0 & 0 & 6,9 & 8 & 0 & 0 & 6,9 & 8 \\
\hline 9. & Analysis of Variance & 75,9 & 88 & 6,9 & 8 & 6,9 & 8 & 3,4 & 4 & 0 & 0 & 6,9 & 8 \\
\hline 10. & Balance sheet analysis & 75,9 & 88 & 6,9 & 8 & 6,9 & 8 & 0 & 0 & 0 & 0 & 10,3 & 12 \\
\hline 11. & Capital Budgeting & 65,5 & 76 & 20,7 & 24 & 6,9 & 8 & 0 & 0 & 3,4 & 4 & 3,4 & 4 \\
\hline 12. & Flexible Budgeting & 51,7 & 60 & 37,9 & 44 & 3,4 & 4 & 3,4 & 4 & 0 & 0 & 3,4 & 4 \\
\hline 13. & $\begin{array}{l}\text { Knowledge on sources } \\
\text { and use of funds }\end{array}$ & 48,3 & 56 & 24,1 & 28 & 0 & 0 & 0 & 0 & 13,8 & 16 & 13,8 & 16 \\
\hline
\end{tabular}

Table two summarizes the research responses and with respect to the responses it might be stated that nearly all of the respondents (112 out of 116) evaluate payroll accounting related issues as easy to learn and apply. On the other hand, only 3,4\% of the respondents evaluate it as time taking to apply. The rest of the management accounting related issues; respectively pricing, recent developments in accounting and finance, payroll taxation, income tax and tax laws, taxation law and property tax; seems to be evaluated as easy to learn and apply. Payroll taxation, taxation law and property tax issues are evaluated as not widespread known or interested issues among industry professionals. Regarding to the time related concerns of accommodation managers it might be stated that pricing is evaluated the most time taking process among the listed issues. A small minority of the respondents evaluated income tax $(3,4 \%)$, taxation law $(3,4 \%)$ and property tax $(6,9 \%)$ related issues are evaluated as not applicable in accommodation industry. Face to face interviews conducted in order to make clear that why a small minority perceived these issues are not applicable revealed that few hotels are using public accountants in order to monitor and fulfill the requirements of tax 
authorities related to these issues. Slightly more than $20 \%$ of the participants reported that they have no idea about the recent developments in accounting and finance such as green accounting, corporate social responsibility reporting and corporate governance. Additionally none of these issues is believed to be effective on the costs.

Table 2: Summary of responses regarding to management accounting issues.

\begin{tabular}{|c|c|c|c|c|c|c|c|c|c|c|c|c|c|}
\hline & \multirow[t]{2}{*}{$\begin{array}{c}\text { Management } \\
\text { accounting issues }\end{array}$} & \multicolumn{2}{|c|}{$\begin{array}{c}\text { Easy to } \\
\text { learn and } \\
\text { apply }\end{array}$} & \multicolumn{2}{|c|}{\begin{tabular}{|c} 
Not \\
widespread \\
among \\
professional \\
s or not easy \\
to learn
\end{tabular}} & \multicolumn{2}{|c|}{$\begin{array}{c}\text { Time } \\
\text { consumin } \\
\text { g to apply }\end{array}$} & \multicolumn{2}{|c|}{$\begin{array}{l}\text { Applicatio } \\
\quad n \\
\text { increases } \\
\text { the costs }\end{array}$} & \multicolumn{2}{|c|}{$\begin{array}{c}\text { Not } \\
\text { applicable } \\
\text { in } \\
\text { accommo } \\
\text { dation } \\
\text { industry }\end{array}$} & \multicolumn{2}{|c|}{ No idea } \\
\hline & & $\%$ & $\mathrm{n}$ & $\%$ & $\mathrm{n}$ & $\%$ & $\mathrm{n}$ & $\%$ & $\mathrm{n}$ & $\%$ & $\mathrm{n}$ & $\%$ & $\mathrm{n}$ \\
\hline 1. & Payroll accounting & 96,6 & 112 & 0 & 0 & 3,4 & 4 & 0 & 0 & 0 & 0 & 0 & 0 \\
\hline 2. & Pricing & 72,4 & 84 & 10,3 & 12 & 10,3 & 12 & 0 & 0 & 0 & 0 & 6,9 & 8 \\
\hline 3. & $\begin{array}{l}\text { Recent developments in } \\
\text { accounting and finance }\end{array}$ & 69,0 & 80 & 10,3 & 12 & 0 & 0 & 0 & 0 & 0 & 0 & 20,7 & 24 \\
\hline 4. & Payroll taxation & 66,5 & 76 & 17,2 & 20 & 3,4 & 4 & 0 & 0 & 0 & 0 & 13,8 & 16 \\
\hline 5. & Income tax and tax laws & 65,5 & 76 & 13,8 & 16 & 3,4 & 4 & 0 & 0 & 3,4 & 4 & 13,8 & 16 \\
\hline 6. & Taxation law & 58,6 & 68 & 17,2 & 20 & 3,4 & 4 & 0 & 0 & 3,4 & 4 & 13,8 & 16 \\
\hline 7. & Property tax & 55,2 & 64 & 17,2 & 20 & 3,4 & 4 & 0 & 0 & 6,9 & 8 & 17,2 & 20 \\
\hline
\end{tabular}

\section{CONCLUSIONS}

Findings revealed that a big majority of the hotel managers, $80 \%$ on average, participating to this research are aware of the management accounting tools and issues. With respect to their evaluation regarding to the limiting factors about the recognition and use of these tools and issues it might be stated that infrequent use of management accounting tools among industry professionals, time consuming nature of some applications, cost increasing effects of some applications, obstacles related to the adoption of some management accounting tools due to the differences between manufacturing industry and service industry are respectively main limitations in accommodation industry. Regarding to the management accounting related issues it might be stated that lack of knowledge in some issues; especially tax laws and taxation procedure; seem to be the least known among the listed issues. Approximately $15 \%$ of the participants reported that they have no idea about these issues. Responses gathered regarding to the "not wide spread among industry professionals" revealed that slightly more than $12 \%$ of the respondents believed that prevalent management accounting tools are frequently used in accommodation industry. This relationship might be commented as a management accounting tool is not referred if it is not a prevalent one among 
industry professionals regardless of its usefulness. On the other hand high rate of responses given as " easy to learn and apply" might be evaluated as the majority of accommodation managers are learning and applying management accounting tools by means of on the job training by supervisors or senior managers.

\section{REFERENCES}

1. Angay,F.(2003),Konaklama şletmelerinde Maliyet ve Yönetim Muhasebesi Problemleri ve Çözüm Önerileri,Akdeniz Üniversitesi,Sosyal Bilimler Enstitüsi,Yayınlanmamış Yüksek Lisans Tezi

2. Angelakis, G., Therious, N. \& Floropoulos, I. (2010). Adoption and benefits of Management Accounting Practices: Evidence from Greece and Finland, Advances in Accounting Incorporating Advances in International Accounting

3. Arzu,Ş. vd.(Temmuz,2015) Örgüt Stratejilerinin Yönetim Muhasebesi Uygulamaları le lişkisi,Aksaray Üniversitesi BF dergisi,cilt 7,Sayı 2

4. Damito, J. D. \& Schmidgall, R. S. (2010). ARe-Examination of Key Managerial Accounting Skills for Lodging Industry Managers, Journal of Hospitality Financial Management, The Professional Refereed Journal of the Association of Hospitality Financial Management Educators, 14(1)

5. Doğan,Ö. \& Kırlığlu,H. (2016) Konaklama şletmeleri Yönetim Muhasebesinin 2000-2014 yılları arası Akademik Gelişim Süreci,Journal Of Accounting ,Finance and auditing studies,2/1,136-161

6. Drury, C. (2012). Management and Cost Accounting, Thomson Learning, London. 7

7. Jagels, M. \& Ralston, C. (2006). Hospitality Management Accounting, John Wiley \& Sons, Inc.

8. Özdoğan,B.(2010)Konaklama şletmelerinde Yönetim Muhasebesi Sistemleri ve Uygulaması ,(yayınlanmamıs yüksek lisans tezi),Celal Bayar Üniversitesi,Sosyal Bilimler Enstitüsi,Manisa

9. Pavlatos,O.\&Paggios,I.(2009),Management Accounting Practises In The Greek Hospitality Industry, Managerial Auditing Journal,24(1)

10. Sulaiman, M., Ahmad, N. N. N. \& Alwi, N. (2004). Management Accounting Practices in Selected Asian Countries, Managerial Auditing Journal, 19(4) 